thought to include in this number the complete presidential address delivered by the Duke before the British Association meeting in Edinburgh in 1951, for that address is still recalled by many as one of the most forcible speeches made in recent years. Dr. Oliver gives a historical account of the Royal Society of New Zealand, which was founded in 1867 as the New Zealand Institute. In the same issue it is announced that publication of a new series of N.Z. Science Abstracts is to begin shortly, and that it is hoped that an abstract will appear within a month of the publication of each paper.

\section{Memorial to Dr. W. G. Duffield at Canberra}

A Memorial tablet to the late Dr. W. G. Duffield was unveiled by his daughter Miss Joan Duffield, in St. John's Church of England, Canberra, on January 3. Dr. Duffeld was the founder and first director of what is now the Commonwealth Observatory, Mt. Stromlo, Canberra, holding office from 1924 to the date of his early death in 1929 at the age of fifty years. The service was held in the presence of many who had been associated with the early development of Canberra. Lessons were read by the present director and Commonwealth Astronomer, Prof. R. v. d. R. Woolley, and the Right Rev. E. H. Burgmann, Bishop of Canberra and Goulburn, who also dedicated the tablet. Sir Robert Garran, in an address recalling the foundation of the Observatory, referred to the earnestness of purpose with which Dr. Duffield fought for so long and for so hard to realize his life's dream. The tablet, in bronze, displays an engraving of the solar tower telescope at Mt. Stromlo which had been one of Dr. Duffield's major interests.

\section{Botany at Swansea : Prof. Florence Mockeridge}

Prof. Florence Mockeridge is retiring at the end of the present session from the chair of biology at the University CCollege of Swansea which she has held since 1921. She was the first holder of the chair and was appointed shortly after the establishment of the College. Naturally she found nothing in existence and she had to lay the very foundations of a Department while simultaneously coping with the demands of teaching. No one who has not had such an experience can readily imagine the sheer hard work involved in such an undertaking, which few of the present generation have had to face and which fewer still will have to face in the future. Our forbears who started scientific teaching in the universities a century ago had none of the complex needs of modern laboratory work to cope with, while students were few and the pace was more leisurely. Prof. Mockeridge devoted her whole energy to the task, which made heavy inroads upon her slender reserves of strength, but she has the unselfish satisfaction of looking back upon a job well done for the benefit of others. She leaves a flourishing organization of well-equipped laboratories, growing numbers of students and an increasing research output.

The Department is primarily botanical with herself as head. Zoology has not hitherto been taken up to full degree standard and was under a zoological lecturer, although Prof. Mockeridge was responsible. Her successor will not have this dual responsibility, as zoology is soon to become independent. Prof. Mockeridge was trained under the late Prof. Bottomley at King's College, London, and did much of the work in investigating the chemistry of his 'auximones', which anticipated the discovery of the auxins. Always young in heart, she has retained a close interest in and sympathy with the work of younger people and has stimulated the research she could no longer do herself. She has been a kind and generous colleague and a wonderful hostess to her fortunate visitors.

Prof. H. E. Street

Dr. H. E. Street, who succeeds Prof. Mockeridge, was born in 1912. He graduated in 1938 at Nottingham as an external student of the University of London, with first-class honours. His first post was on microbiological control work in industry ; meanwhile, he enrolled as an evening research student at, Birkbeck College under Dr. F. C. Steward. Upon this foundation Dr. Street has built an impressive amount of research on cell metabolism, distinguished for its thoroughness and its grasp of the fundamental problems of chemical physiology. Since going to Manchester in 1949, Dr. Street has established a vigorous research school and has made his laboratory a centre for the study of metabolism in excised roots. $\mathrm{He}$ brings to his new post experience as lecturer in the Universities of Nottingham and Manchester, a wide knowledge of modern techniques in plant physiology, and a store of energy and enthusiasm which will be of great benefit in the programme of development which is about to begin in the biological sciences at University College, Swansea.

\section{Katharine Berkan Judd Awards for Cancer Research}

THE Katharine Berkan Judd Awards of the Memorial Center for Cancer and Allied Diseases and its research unit, the Sloan-Kettering Institute, have been made to the following for their outstanding contributions in the field of cancer research: Dr. Evarts A. Graham, of the Washington University School of Medicine, St. Louis; Dr. George O. Gey, of the Johns Hopkins University School of Medicine, Baltimore; Dr. L. H. Gray, of the Mount Vernon Hospital, Northwood, Middlesex, England; and Dr. Sidney Farber, of the Harvard Medical School, Boston. Dr. Graham's Award is in recognition of his work in cancer surgery and in medical education; he was the first surgeon to remove an entire lung in the treatment of cancer, the patient being still alive to-day twenty years after the operation, and he was also one of the first to work on a possible relationship between lung cancer and tobacco smoke. Dr. Gey's contributions have been in the field of tissue culture, which is important not only for cancer but also for studies of poliomyelitis and other medical research, and in particular he made the long-term culture of human cancer cells known as the HeLa strain, which has been used as a medium for the growth of the polio virus all over the world. Dr. L. H. Gray is a physicist whose speciality is the investigation of the effect of ionizing radiations in normal and cancer cells and the application of this knowledge to radiation therapy. The complementary side of Dr. Gray's treatment by physical methods is represented by Dr. Farber's work in the field of cancer treatment by chemicals; among Dr. Farber's most notable achievements have been his demonstrations that certain chemicals can preferentially damage the cells of certain types of acute leukæmia in children, and this has opened a new field in cancer chemotherapy. The Awards are given in memory of Katharine Berkan Judd, who left a portion of her estate to the Memorial Center for recognition of achievements in the field of cancer, and the recipients, who by 